\title{
God's eyes and the schizophrenic hands: listening to a psychiatric patient
}

Luciane Loss Jardim Clarissa R. Dantas Fabricio Z. Miranda Claudio E.M. Banzato

This article describes the intriguing case of a young female patient first seen in the emergency room and then followed up at the psychiatric outpatient facility of the General Hospital at UNICAMP, Brazil. The cooperation that ensued between psychiatrists and a psychoanalyst to reach a psychopathological diagnosis is also presented here. The differential diagnosis is discussed within a psychiatric framework and then contributions from listening to the patient's free associations related to the clarification of her psychopathology are described. The clinical collaboration between psychiatry and psychoanalysis proved effective in this case as a clinical method for approaching the patient.

Key words: Psychopathology, psychiatry, psychoanalysis, case report, clinical method 


\section{An intriguing case at a psychiatric ER}

In an autumn morning of 2008, a young woman aged $21, \mathrm{~K}$, who lived in a small town, was brought to our psychiatric emergency at the University of Campinas (Unicamp) hospital by her aunt because she had been covering her face with her hands for a long time. When asked to account for such behavior, she said quite vaguely that it had something to do with her ugliness and shame and explained no further. No one, not even close relatives, had by then seen her face for months. Besides, she kept whispering words barely audible. Confronted with the inevitable question "what did you say?" she usually answered she was just singing and then started actually doing that out loud. She finished high school due to the helpful assistance of her teachers, given the fact that she eventually became unable to attend the classes, as she felt very uncomfortable in front of her classroom mates. She resented very much sexual jokes made at her expense, to which she responded aggressively. She even took a knife to the school once. It was back then, feeling she was under close scrutiny of colleagues that she started covering her face with her hands and towels. She thought her ugliness was commented on by them and that her looks was ridiculed. After that, she became progressively withdrawn. She was at ease only with small children. Recently, she was staying home idle all day long. K's mother at first thought that such behavior of her was just childish and silly, but after a while it began to strike her as odd, worrying about it because of its persistence. She had sought medical care for her daughter in a nearby town. $\mathrm{K}$ was treated with fluoxetine (up to $80 \mathrm{mg} / \mathrm{d}$ ) and risperidone $6 \mathrm{mg} / \mathrm{d}$ for 6 months without any clinical improvement. In the following two years they sought different care settings and although they could not report precise doses and treatment duration they knew $\mathrm{K}$ had already taken: fluvoxamine, clomipramine, alprazolam, haloperidol and olanzapine, without any response, except perhaps for the fact that $\mathrm{K}$ uncovered her face for a few days while taking alprazolam (most interestingly, its brand name in Brazil is Frontal®).

Rev. Latinoam. Psicopat. Fund., São Paulo, v. 13, n. 4, p. 577-584, dezembro 2010 
Her mother then took $\mathrm{K}$ to her aunt's house in the city of Campinas looking for psychiatric expert opinion at the university hospital. After her visit to our psychiatric emergency unit, $\mathrm{K}$ was referred to our outpatient clinic, where she would be followed by a psychiatry resident (FZM) under supervision of an attending psychiatry (CRD) and a senior consultant psychiatrist (CEMB).

\section{Differential diagnosis}

Initially, three diagnostic hypotheses were raised according to the DSM-IVTR (APA, 2002): psychotic disorder (possibly schizophrenia), body dysmorphic disorder and social phobia. In favor of the first one, it could be enlisted the oddness of her behavior of covering her face with the hands, which might well be due to a delusion or hallucinatory commands, or even some sort of stereotyped gesture. Indeed, she was withdrawn and self-referent (Meyer; Lenzenweger, 2009) and her whispers could well be taken as mussitations. However, when confronted, she responded with a coherent speech denying any kind of hallucinations. No delusional ideas were evident either. Again, she would just allude vaguely (and quite shyly) to her supposed ugliness.

It was conceivable to think also of a dysmorphic body disorder. In this case, either an imagined or actual slight physical defect, noticeable by others, would be the object of concern and much distress. Often, the face is the site of the defect (nose, skin, eyes, mouth etc.), but sometimes, out of shame, patients refer only in general terms to their supposed ugliness (Cororve; Gleaves, 2001). Ideas of self-reference may be present and social isolation may follow. The worry can reach delusional proportions (Philips et al., 2008). In K's case, no specific defect was ever mentioned by her. In addition, during the interviews, she typically struggled to keep her face covered while, at the same time, seemingly out of modesty, she tried to move her blouse and skirt to hide her cleavage and thighs.

Because a severe social isolation was a central feature of the case and because she attributed this to the feelings of discomfort and embarrassment in social situations, the diagnosis of social phobia had to be considered as well (Stein; Stein, 2008). But the patient did not think that perhaps her worry was excessive or unreasonable (that is, there was no insight), nor she presented any autonomic symptoms and signs of anxiety. Thus, diagnostic criteria for social phobia could not be met.

Though the aggressive behavior displayed by $\mathrm{K}$ at school on a few occasions could be interpreted as a paranoid psychotic behavior, an understandable 
psychological response to episodes perceived as bullying could not be rule out for sure. As a matter of fact, she looked a bit clumsy (though this could well result from her efforts to keep the face hidden).

Considering some of K's clinical features like odd behavior, social withdraw and functional impairment, we opted for first prescribing an antipsychotic (olanzapine, up to $30 \mathrm{mg} / \mathrm{d}$ ) even though a definite diagnosis could not be established by then.

So, in order to find more about her and to help the diagnostic process, in addition to the weekly appointments with the psychiatrist in charge of her treatment, interviews with a psychoanalyst (LLJ) were arranged. In these interviews, K was invited to speak freely of whatever subject she felt like addressing to. The gains brought about by such listening effort are presented right below.

\section{Listening to $\mathrm{K}$}

The rationale behind non-directed interviews is that it would assumingly better reveal the internal logic of the speech of the subject. When an interviewee is freely associating, unexpected things about him or her are often said, which may lead to a finer grasp of his or her mental condition.

At first, the most prominent feature of K's speech was some sort of continuity between her reports of daily facts and night dreams. She seemed not to realize the difference between these two registers of reality. For example, after reporting a dream about a coffin waiting for her in the cemetery, supposedly put there by the boys of her school, she characterized the way they usually looked at her as something evil, though they found her pretty. The girlfriends of these boys were jealous of $\mathrm{K}$, as they were always flirting with her. Then, $\mathrm{K}$ said that her hands were protecting her from being beaten by her family, the boys at school and their jealous girlfriends for her striking beauty. Actually, K added, since she was a little child she looked like a princess. Incidentally, K mentioned a beautiful picture of her she posted in the social net-working website Orkut.

$\mathrm{K}$ usually commented on some books she read and soap operas she saw at the television. Sometimes, it went beyond that, as she seemed to converse with the characters. Such dialogues were invariably erotic and her strong sexual urges were manifest.

In one interview, she told a story about a girl who seeks a psychiatrist. They become friends. She finds him attractive, and his blue eyes fascinate her. She goes 
out with him "in order to forget and she accomplishes that". The sexual interest for her psychiatrist grows. Then she started referring to him as "an adorable spy".

Besides the fear of being beaten by others, she also talked a lot about shame in order to justify her hands up her face all the time. The shame, according to $\mathrm{K}$, was associated to her religious upbringing and the rigid moral precepts she held about sexual activity of single girls. She felt guilty because of her sexual urges and, especially, for being unable to resist to it, as she masturbated constantly.

Interestingly, one expression came up very often, "only God". What at first sound like as an appeal to the almighty God from a religious girl in deep distress, turned out to be much more than this, God's eyes were actually at the center of her worries. It finally became clear that she felt that God was looking at her all the time, seeing everything she was doing. So, K said at last, she hoped that the doctors would help to cure "her hands".

\section{Final remarks}

The very hands she used to masturbate also protected her from God's unbearable gaze. The hands were sick, not her. The persecutory delusion started then to unfold and her whispers turned out to be responses to audio verbal hallucinations. The diagnosis of paranoid schizophrenia could thus be established in firm grounds. Eventually $\mathrm{K}$ was considered treatment-resistant and was prescribed clozapine (up to $700 \mathrm{mg} / \mathrm{d}$ ), which reduced some of the symptoms. The overall response to clozapine has unfortunately been modest so far.

The close collaboration between the psychiatric team in charge and the consulting psychoanalyst was found to be helpful in this case both to the patient's clinical management and to the psychiatric training of the medical resident involved, enhancing core competencies such as patient care and interpersonal and communications skills (Scheiber; Kramer; Adamovich, 2003).

Nowadays, this kind of clinical collaboration for approaching the patient is not very usual. It may be the case that conflicts of interest sometimes get in the way, preventing a fruitful collaboration from being established. We argue that such 'turf war' does not serve the study of psychopathology, and much less the treatment of our patients.

Listening to the patient freely associating in the psychoanalytic interviews and carefully observation and description of symptoms in the psychiatry clinic can be brought together, in order to further refine our understanding of psychopathology, helping us to help the patients. As this case report illustrates,

Rev. Latinoam. Psicopat. Fund., São Paulo, v. 13, n. 4, p. 577-584, dezembro 2010 
the discussion that takes into account different perspectives of psychopathology (each of them with their own assumptions) makes better justice to the complexity of the predicaments and suffering faced by human beings, the very subject matter of psychopathology.

\section{References}

American Psychiatric Association. Diagnostic and statistical manual of mental disorders, fourth edition, text revision. Washington (DC): American Psychiatric Association, 2002.

Cororve, M.B.; Gleaves, D.H. Body dysmorphic disorder: a review of conceptualizations, assessment, and treatment strategies. Clin Psychol Rev, v. 21, n. 6, p. 949-970, 2001.

Meyer, E.C.; Lenzenweger, M.F. The specificity of referential thinking: a comparison of schizotypy and social anxiety. Psychiatr Res, v. 165, n. 1, p. 78-87, 2009.

Phillips, K.A.; Didie, E.R.; Feusner, J.; Wilhelm, S. Body dysmorphic disorder: treating an underrecognized disorder. Am J Psychiatry, v. 165, n. 9, p. 1111-1118, 2008.

Scheiber, S.C.; Kramer, T.A.M.; Adamovich, S.E. The implications of core competencies for psychiatric education and practice in the US. Can J Psychiatry, v. 48, p. 215-221, 2003.

Stein, M.B.; Stein, D.J. Social anxiety disorder. Lancet, v. 371, n. 9618, p. 1115, 2008.

\section{Resumo}

(Os olhos de Deus e as mãos esquizofrênicas: escutando um paciente psiquiátrico)

Relatamos um intrigante caso de uma jovem paciente atendida no Pronto-Socorro e, depois, no Ambulatório de Psiquiatria do HC-UNICAMP, e descrevemos a colaboração estabelecida entre psiquiatras e psicanalista, com o intuito de realizar um diagnóstico psicopatológico. Discutimos a sintomatologia e o diagnóstico diferencial da paciente em termos médicos e mostramos, a partir de alguns fragmentos da escuta das associações livres do paciente, como o quadro psicopatológico foi finalmente elucidado. A colaboração clínica entre a psiquiatria e psicanálise se mostrou profícua neste caso, como método clínico, na abordagem do sujeito psicopatológico.

Palavras-chave: Psicopatologia, psiquiatria, psicanálise, relato de caso e método clínico 
(Les yeux de Dieu et les mains schizophrènes: à l'écoute d'un patient de psychiatrie)

Nous rapportons un cas fascinant d'une jeune patiente traitée à la Salle d'Urgence, puis à la Clinique de Psychiatrie de l'Hôpital des Cliniques de l'UNICAMP et décrivons ensuite la collaboration entre psychiatres et psychanalystes pour établir un diagnostic psychopathologique. Nous discutons les symptômes et le diagnostic différentiel de la patiente en termes médicaux et montrons à partir de quelques fragments d'associations libres de la patiente comment le cadre psychopathologique a finalement été élucidé. Dans ce cas, la collaboration clinique entre la psychiatrie et psychanalyse s'est révélée fructueuse et peut être considérée comme méthode clinique dans le traitement du sujet psychopathologique.

Mots clés: Psychopathologie, psychiatrie, psychanalyse, rapport de cas et méthode clinique

(Los ojos de Dios y las manos esquizofrénicas: escuchando un paciente psiquiátrico).

Relatamos el caso instigador de una joven paciente tratada en la sala de emergencia y después en la Clínica de Psiquiatría del HC-UNICAMP; describimos también la cooperación establecida entre psiquiatras y psicoanalista para la realización del diagnóstico de la psicopatología. Discutimos la sintomatología y el diagnóstico diferencial de la paciente en términos médicos y mostramos, a partir de algunos fragmentos de la escucha de las asociaciones libres del paciente, cómo el cuadro psicopatológico fue elucidado. La colaboración clínica entre psiquiatría y psicoanálisis se mostró provechosa en este caso como método clínico en el abordaje del sujeto psicopatológico.

Palabras claves: Psicopatología, psiquiatría, psicoanálisis, historial clínico y método clínico

Citação/Citation: Jardim, L.L.; Dantas, C.R.; Miranda, F.Z.; Banzato, C.E.M. God's eyes and the schizophrenic hands: listening to a psychiatric patient. Revista Latinoamericana de Psicopatologia Fundamental, São Paulo, v. 13, n. 4, p. 577-584, dez. 2010.

Editor do artigo/Editor: Prof. Dr. Manoel Tosta Berlinck

Recebido/Received: 5.10.2009 / 10.5.2009 Aceito/Accepted: 20.1.2010/ 1.20.2010

Copyright: (C) 2009 Associação Universitária de Pesquisa em Psicopatologia Fundamental/ University Association for Research in Fundamental Psychopathology. Este é um artigo de livre acesso, que permite uso irrestrito, distribuição e reprodução em qualquer meio, desde que o autor e a fonte sejam citados/This is an open-access article, which permits unrestricted use, distribution, and reproduction in any medium, provided the original author and source are credited.

Rev. Latinoam. Psicopat. Fund., São Paulo, v. 13, n. 4, p. 577-584, dezembro 2010 
Financiamento/Funding: Os autores declaram não ter sido financiados ou apoiados/The authors have no support or funding to report.

Conflito de interesses/Conflict of interest: Os autores declaram que não há conflito de interesses/The authors declare that has no conflict of interest.

\section{LUCIANE Loss JARDIM}

Ph.D. Fellow researcher of the Laboratory of Fundamental Psychopathology at the Department of Psychiatry, Medical School, University of Campinas - Unicamp (Campinas, SP, Brasil) and Fellow researcher of the Laboratory of Fundamental Psychopathology and Psychoanalysis at the School of Psychology, University of San Luis Potosí - UASLP (Mexico, Mx); Member Psychoanalyst of the Psychoanalytic Association of Porto Alegre - APPOA (Porto Alegre, RS, Brasil); Former Professor of Psychology (2005-2007) and currently invited Professor of the Graduate Program of Psychology of the University of San Luis Potosí - UASLP (since 2009).

Rua João Simões da Fonseca, 362

13085-858 Campinas, SP, Brasil

Fone: (19) 3305-1808

e-mail: lulossjardim@uol.com.br

\section{Clarissa R. Dantas}

M.D., MSc., Attending psychiatrist, Department of Psychiatry, Medical School, University of Campinas - Unicamp (Campinas, SP, Brasil).

Rua Boaventura do Amaral, 1190, apto. 13 - Centro

13015-192 Campinas, SP, Brasil

e-mail: dantascr@gmail.com

\section{Fabricio Z. Miranda}

M.D., Psychiatry resident (PGY2), Department of Psychiatry, Medical School, University of Campinas - Unicamp (Campinas, SP, Brasil).

Rua Alzira de Aguiar Aranha 354 - Barão Geraldo (Jardim Santa Genebra II)

13084-768 Campinas, SP, Brasil

e-mail: fabricio.zache@terra.com.br

\section{Claudio E. M. Banzato}

M.D., Ph.D., Associate Professor of Psychiatry, Department of Psychiatry, Medical School, University of Campinas - Unicamp (Campinas, SP, Brasil).

R. Egberto F. A. Camargo 1200, apto. 52C

13092-621 Campinas, SP, Brasil

e-mail: cbanzato@fcm.unicamp.br 